\title{
WATER FLOW THROUGH A GLACIER SITUATED IN AN OVERDEEPENING: CAUSE OR CONSEQUENCE OF A TILL LAYER AT THE BED
}

\section{(Abstract)}

by

Roger LeB. Hooke

(Department of Geology and Geophysics, University of Minnesota, Minneapolis, MN 55455, U.S.A.)

Beneath the upper part of the ablation area of Storglaciären, northern Sweden, the glacier bed is overdeepened. The overdeepening has a closure of $\sim 60 \mathrm{~m}$.

Electrical resistivity measurements in bore holes indicate that a layer of till, $\sim 0.5 \mathrm{~m}$ thick, lies between the glacier and the bed in this overdeepening in at least one place; we infer that this till layer underlies the glacier throughout the better part of this overdeepening.

Of about 40 holes drilled to the bed in this overdeepening between 1982 and 1987, 70\% "drained" when the drill tip had penetrated between $\sim 40$ and $\sim 95 \%$ of the glacier thickness. When measured after completion of drilling, however, the water levels were only $20-45 \mathrm{~m}$ below the glacier surface, and were relatively stable, varying only $5-10 \mathrm{~m}$, say, in a period of several days. These levels correspond to basal water pressures on the order of $80-90 \%$ of overburden pressure. In contrast, water levels further down-glacier vary up to $50-100 \mathrm{~m}$ diurnally during good weather. This brings us to the first of two questions:

What sort of "dam" maintains water levels in the overdeepening several tens of metres above the low point of the riegel at the down-glacier end of the overdeepening?
Tracer tests indicate that at least three of the bore holes that "drained" intersected englacial drainage channels at the levels where the drill tip stood when the water level dropped from the surface. Other tracer tests indicate that water passing through the overdeepening appears at the terminus in a stream that carries little sediment. In contrast, tracer tests further down-glacier indicate that water disappearing down moulons over the riegel appears in another stream that carries a lot of sediment. Thus, water flow through the overdeepening is inferred to be englacial. This raises the second question:

Is the water flow englacial because the till layer is present, and the till layer squeezes into incipient subglacial channels, closing them? If so, why is the till layer present?

Alternatively, is the till layer present because the water flow is englacial, and thus there is no flushing along the bottom to remove the products of erosion? If so, why is the drainage englacial? Is it because water flowing up an adverse slope must warm to remain at the pressure-melting point? If slopes are steep enough, such warming can require refreezing which would tend to close subglacial channels.

\section{MEGA-GIANT ICEBERG CALVED FROM THE ROSS ICE SHELF, ANTARCTICA}

\author{
(Abstract) \\ by \\ Harry (J.R.) Keys \\ (Department of Conservation, P.O. Box 10-420, Wellington, New Zealand)
}

A recent major calving of the Ross Ice Shelf has implications for estimates of mass balance of the ice shelf, iceberg-calving rates, and our knowledge of ocean currents in the vicinity.

\section{The calving}

The mega-giant B-9 iceberg calved from the Bay of Whales, in the eastern Ross Ice Shelf to the western Byrd Land coast, in late September-early October 1987. Measuring $154 \mathrm{~km} \times 35 \mathrm{~km}$, it averages probably about $240 \mathrm{~m}$ thick and has a volume of $1100 \mathrm{~km}^{3}$. The total volume calved $\left(1200 \mathrm{~km}^{3}\right)$ is about eight times the average annual calving rate of the Ross Ice Shelf as estimated by Jacobs and others (1986), and is $30-100 \%$ of the annual rate of iceberg production from the whole Antarctic ice sheet.

\section{Major calvings are episodic}

It is now well known that such major calvings are episodic. The front of the ice shelf in the east was further north than it had been (Jacobs and others, 1986) this century. Clearly, the ice front does not maintain a precise equilibrium position. Major calvings may produce changes in strain-rates up-flow and in iceberg distribution. providing information on sea currents near the Ross Ice Shelf. B-9 moved west initially then collided with the ice shelf, thereafter rotating anti-clockwise and drifting north-west to north. This north-west drift may be forced in part by an outflow from beneath the eastern Ross Ice Shelf, which might affect basal conditions there. Meanwhile, cocalved icebergs drifted parallel to the ice front at up to $11 \mathrm{~km} / \mathrm{d}$, five times as fast as B-9. The northward drift ended in late May. Between early July and mid-August 1988 B-9 moved southward in long. $172-173^{\circ} \mathrm{W}$, possibly forced by the warm core current flow mentioned in Jacobs and others (1986).

\section{ACKNOWLEDGEMENT}

I am grateful to the U.S. Navy/NOAA Joint Ice Center in Maryland, U.S.A., for sending me B-9 position data, and to H.J. Zwally for size information.

\section{REFERENCE}

Jacobs, S.S., D.R. MacAyeal, and J.L. Ardai, jr. 1986. The recent advance of the Ross Ice Shelf, Antarctica. $J$. Glaciol., 32(112), 464-474. 